\title{
Pendekatan Metode Pohon Keputusan Menggunakan Algoritma ID3 Untuk Sistem Informasi Pengukuran Kinerja PNS
}

\author{
Julce Adiana Sidette $^{\mathrm{a}^{*}}$, Eko Sediyono ${ }^{\mathrm{b}}$, Oky Dwi Nurhayati $^{\mathrm{c}}$ \\ ${ }^{a}$ STMIK Uyelindo Kupang, NTT \\ ${ }^{\mathrm{b}}$ Fakultas Teknologi Informasi Universitas Kristen Satya Wacana Salatiga \\ ${ }^{c}$ Fakultas Teknik Universitas Diponegoro Semarang
}

Naskah Diterima : 12 Januari 2014; Diterima Publikasi : 20 Maret 2014

\begin{abstract}
Decision tree method is a classification method that has been widely used for the solution of problems of classification. Decision tree classification provides a rapid and effective method. The approach has been proven decision tree method can be applied in various fields of life. Capability classification is indicated by the decision tree method is what encourages authors to use decision tree methods approach to measure the performance of civil servants. To build a decision tree induction algorithms used. In this study, the ID3 algorithm method is used to construct a decision tree. Starting with the data collecting training samples and then measuring the entropy and information gain. Information Gain value will be used as the root of a decision tree. And translates it into a decision tree classification rules. The results show that the decision tree method is used to produce classification rules into groups employee performance Good and Bad. The resulting rules are used to measure the performance of employees and classifying employees into two groups above are constructed in an information system. Information system built to assist management in making more objective assessment process.
\end{abstract}

Keywords: ID3 Algorithm; Decision tree; Employee performance

\begin{abstract}
Abstrak
Metode pohon keputusan merupakan metode klasifikasi yang telah banyak digunakan untuk penyelesaian masalah-masalah klasifikasi. Klasifikasi pohon keputusan menyediakan metode yang cepat dan efektif. Pendekatan metode pohon keputusan telah terbukti dapat diaplikasikan dalam berbagai bidang kehidupan. Kemampuan klasifikasi yang ditunjukan oleh metode pohon keputusan inilah yang mendorong penulis menggunakan pendekatan metode pohon keputusan untuk mengukur kinerja pegawai negeri sipil. Untuk membangun sebuah pohon keputusan digunakan algoritma induksi. Pada penelitian ini, metode Algoritma ID3 digunakan untuk membangun sebuah Pohon Keputusan. Dimulai dengan menggumpulkan sampel training data kemudian mengukur entropy dan informationgain. Nilai Information Gain akan digunakan sebagai Root sebuah pohon keputusan. Pohon keputusan kemudian diterjemahkan dalam aturan klasifikasi. Hasil penelitian menunjukkan bahwa metode pohon keputusan yang digunakan menghasilkan aturan klasifikasi kinerja pegawai kedalam kelompok Bagus dan Buruk. Aturan yang dihasilkan ini digunakan untuk mengukur kinerja pegawai dan mengelompokkan pegawai kedalam dua kelompok diatas yang dibangun dalam sebuah sistem informasi. Sistem informasi yang dibangun dapat membantu pihak menajemen dalam melakukan proses penilaian yang lebih objektif.
\end{abstract}

Kata kunci: Algoritma ID3; Pohon keputusan; Kinerja pegawai

\section{Pendahuluan}

Kinerja pegawai adalah salah satu unsur yang sangat menentukan kualitas suatu organisasi baik pemerintah maupun swasta. Bagi sebuah perusahan, entah itu perusahan produksi maupun jasa, karyawan menjadi ujung tombak dari perusahaan (Wibisono, 2011). Pada instansi pemerintahan, pegawai merupakan pelayan masyarakat yang menjamin nama baik dari sebuah instansi dan unit kerja (Safroni, 2012). Dengan fungsi yang sangat penting inilah maka kinerja pegawai perlu dikelola secara baik.

*) Penulis korespondensi: utje_caem@yahoo.com
Kinerja pegawai perlu diukur untuk menentukan apakah profesionalisme pegawai telah tercapai secara maksimal.

Pengukuran kinerja pegawai telah banyak dilakukan. Pengukuran kinerja manusia(human performance) dapat menaikan tingkat produktifitas dari sebuah perusahaan selain dari kinerja sistem keuangan (McLean, 2009). Pengukuran kinerja dapat merangsang inisiatif karyawan untuk meningkatkan operasional kinerja, terutama ketika karyawan sendiri berpartisipasi dalam pengembangan ukuran kinerja departemen mereka sendiri (Groen et al., 2012). 
Pengukuran kinerja secara rinci masing-masing pegawai perlu dilakukan untuk mencapai kinerja yang unggul. Keunggulan operasionaldicapai melalui mekanisme yang didasarkan pada kepercayaan dan tanggung jawab pegawai (Platts dan Sobotka, 2010). Selain pengukuran yang dilakukan oleh pihak manajemen, evaluasi kinerja juga dapat dilakukan berdasarkan prespektif pelangan khususnya bagi perusahaan pengelola produk jasa (Noone, 2008). Begitu pentingnya pengukuran kinerja maka metode optimalisasi pengukuran kinerja terus dikembangkan, contohnya seperti konsep analisis maximal dan typical kinerja yang dilakukan dari waktu ke waktu (Diana dan Donald, 2008).

Kinerja Pegawai Negeri Sipil (PNS) diukur berdasarkan pelayanan yang diberikan kepada masyarakat. Kualitas pelayanan akan teruji dengan kepuasan yang dirasakan sebagai dampak dari pelayanan itu sendiri. Selain kepuasan masyarakat, penilaian kinerja PNS masih ditentukan dengan aspek-aspek lainnya. Undang-Undang No. 43 Tahun 1999 tentang Pokok-pokok Kepegawaian mengisyaratkan 8 unsur penilaian yang menjadi faktor penentu kualitas kinerja PNS. Ke-delapan unsur tersebut adalah kesetiaan, prestasi kerja, tanggung jawab, ketaatan, kejujuran, kerjasama, prakarsa dan kepemimpinan seperti yang tertuang dalam format Daftar Penilaian Pelaksanaan Pekerjaan (DP3).

Sistem pengukuran kinerja PNS yang selama ini dilakukan adalah menggunakan teknik rating scale dan critical incident method. Sistem pengukuran ini merupakan sistem penilaian yang berorientasi pada masa lalu, sehingga apabila tidak dilakukan sebagaimana mestinya hal ini bisa menimbulkan adanya bias penilaian berupa bias liniency effect, central tendency effect, dan recency effect. Dimana kecenderungan proses penilaian dengan sistem ratarata dan berdasarkan perilaku yang baru saja dilihat. Penilaian dengan sistem ini memberikan tingkat subjektifitas yang sangat tinggi. Sehingga pengukuran kinerja PNS yang lebih objektif merupakan sebuah kebutuhan yang harus dipenuhi dalam rangka perbaikan kualitas dan performa PNS itu sendiri.

Metode decision tree atau pohon keputusan merupakan metode klasifikasi yang telah banyak digunakan untuk penyelesaian masalah-masalah klasifikasi.Klasifikasi pohon keputusan menyediakan metode yang cepat dan efektif untuk mengelompokkan dataset (Aitkenhead, 2008). Bahkan pengembangan terhadap metode pohon keputusan telah dilakukan untuk menghasilkan pendekatan yang mampu mengklasifikasi data-data sensitif (Barak dan Gelbard, 2011). Pendekatan metode pohon keputusan telah terbukti dapat diaplikasikan dalam berbagai bidang kehidupan. Penggunaan algoritma induksi pohon keputusan pada data Rumah Sakit Surveilans untuk mengklasifikasikan pasien berdasarkan kondisi kritis yang dialami (Rahman dan Hasan, 2011). Pembangunan Intrusion Detection System (IDS) berbasis pohon keputusan untuk mendeteksi anomali dalam jaringan (Sindhu et al., 2012). Metode pohon keputusan juga dapat dikombinasikan dengan metode lain untuk hasil penyelesaian masalah yang lebih maksimal. Pendekatan sistematis untuk merancang desain konsep produk konvergen atau digital berdasarkan informasi komunitas online menggunakan teknik data mining ARM dan pohon keputusan (Lee et al., 2012). Pohon keputusan dan algoritma genetika untuk pemantauan kondisi AC pesawat (Gerdes, 2013). Optimasi metode koloni semutberbasis Fuzzy biner pohon keputusan untuk sistem verifikasi pola tangan (Kumar et al., 2013).

Untuk membangun sebuah pohon keputusan, digunakan algoritma induksi. Algoritma induksi yang dikenal antara lain : ID3, CART, C4.5, SLIQ, PUBLIK, SPRINT, RAINFOREST, BOAT, MMDT, danTASC (Chen dan Hung, 2009). Masing-masing algoritma memiliki kemampuan yang berbeda-beda sesuai dengan studi kasus dan pemasalahan. Algoritma ID3 memiliki kemampuan klasifikasi yang paling sederhana. Algoritma ID3 adalah konsep algoritma pembelajaran yang bermanfaat karena dapat membangun pohon keputusan secara baik dan efisien (Balamurugan dan Rajaram, 2009). Untuk kasus-kasus pembelajaran yang sederhana, algoritma inisering merupakan pilihan yang ideal untuk membangun aturan klasifikasi.

Kemampuan klasifikasi yang ditunjukkan oleh metode pohon keputusan seperti yang dijelaskan diatas dan kesederhaan proses yang ditawarkan oleh algoritma ID3, maka pada penelitian ini akan dilakukan suatu sistem analisis klasifikasi terhadap kinerja PNS untuk menentukan tingkat profesionalisme pegawai. Pendekatan yang digunakan adalah metode pohon keputusan dengan algoritma ID3 (Iterative Dichotomiser 3).

\section{KerangkaTeoritis}

\subsection{Pohon Keputusan}

Pohon keputusan adalah sebuah struktur data yang terdiri dari simpul (node) dan rusuk (edge) simpul pada sebuah pohon dibedakan menjadi tiga, yaitu simpul akar (root node), simpul percabangan (branch node) dan simpul daun atau leaf node (Hermawati, 2013).

Pada sebuah pohon keputusan setiap node merepresentasikan atribut yang telah diuji, setiap cabang merupakan suatu pembagian hasil uji, dan node daun (leaf) merepresentasikan kelompok kelas tertentu. Level node teratas dari sebuah pohon keputusan adalah node akar (root) yang biasanya berupa atribut yang memiliki pengaruh terbesar pada suatu kelas tertentu. Pada umumnya pohon keputusan melakukan strategi pencarian secara top-down untuk 
solusinya. Pada proses mengklasifikasi data yang tidak diketahui, nilai atribut akan diuji dengan cara melacak jalur dari node akar (root) sampai node akhir (daun) dan kemudian akan diprediksi kelas yang dimiliki oleh suatu data baru tertentu. Proses dalam pohon keputusan yaitu mengubah bentuk data (tabel) menjadi model pohon (tree) kemudian mengubah model pohon tersebut menjadi aturan (rule).

Model pohon keputusan ditunjukan pada Gambar 1 berikut ini (Aitkenhead, 2008):

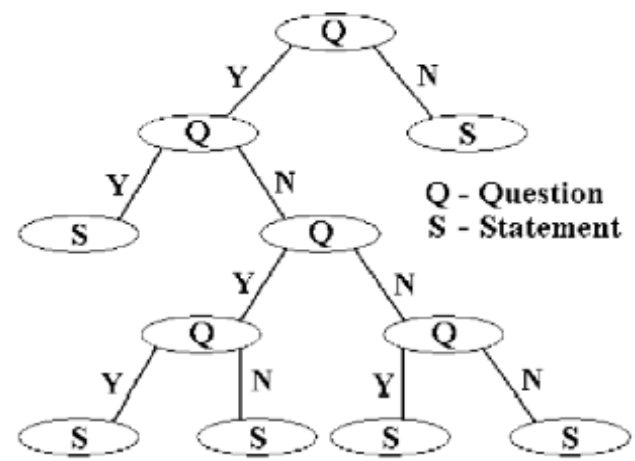

Gambar 1. Gambaran sebuah pohon keputusan

Pohon keputusan merupakan himpunan aturan IFTHEN. Tahap awal dilakukan pengujian simpul akar yang ditandai dengan simbol Q (Question), jika pada pengujian simpul akar atau memenuhi syarat memilih yang dilambangkan dengan $\mathrm{Y}$ (Yes) dan $\mathrm{N}$ (No) lalu menghasilkan sesuatu maka proses pengujian juga dilakukan pada setiap cabang berdasarkan hasil dari pengujian. Hal ini berlaku juga untuk simpul internal dimana suatu kondisi pengujian baru akan diterapkan pada simpul daun berikutnya.

Untuk membangun pohon keputusan digunakan algoritma, ada beberapa teknik algoritam yang biasa digunakan seperti: Algoritma Hunt, CART (Classification And Regression Tree), CHAID (Chisquared Automatic Interaction Detector), QUEST (Quick Unbiased Efficient Statistical Tree), Commercial version 4.5 (C4.5) and Interactive Dichotomizer version 3 (ID3). Masing-masing metode memiliki keunggulan dan kelemahan tersendiri tergantung penggunaan pada jenis masalah data klasifikasi (Ture et al., 2009).

\subsection{Algoritma ID3 (Iterative Dechotomizer 3)}

Penelitian ini menggunakan algoritma ID3 (Iterative Dechotomizer 3). Algoritma ID3 adalah algoritmapembelajaranpohon keputusanyang sederhana dikembangkan oleh J. Ross Quinlan pada tahun 1993. AlgoritmaID3melakukan prosedur pencarian secara menyeluruh pada semua kemungkinan pohon keputusan.Ide dasar darialgoritmaID3 adalahuntuk membangunpohon keputusandengan menggunakan sebuah top-down, pencairan menyeluruhmelaluisetyang diberikanuntuk menguji masing-masing atribut pada setiap simpul pohon (Ture et al., 2009). ID3 diimplementasikan menggunakan fungsi rekursif ( fungsi yang memanggil dirinya sendiri). Algoritma ID3 berusaha membangun pohon keputusan secara top-down (dari atas ke bawah), mulai dengan pertanyaan : "atribut mana yang pertama kali harus dicek dan diletakkan pada root?" pertanyaan ini dijawab dengan mengevaluasi semua atribut yang ada dengan menggunakan suatu ukuran statistik yang banyak digunakan adalah information gain untuk mengukur efektivitas suatu atribut dalam mengklasifikasikan kumpulan sampel data. Secara ringkas, langkah kerja algoritma ID3 dapat digambarkan sebagai berikut (Defiyanti dan Pardede, 2009) :

1. Input sampel training, label training, dan atribut.

2. Hitung Entropy dan Information Gain dari setiap atribut dengan rumus

Entropy $(\mathrm{S})=-\mathrm{P}_{+} \log _{2} \mathrm{P}_{+}-\mathrm{P}_{-} \log _{2} \mathrm{P}_{\text {. }}$

Dimana:

$\mathrm{S}$ = ruang (data) sample yang digunakan untuk training.

$\mathrm{P}+=$ jumlah yang bersolusi positif (mendukung) pada data sample untuk kriteria tertentu.

P- = jumlah yang bersolusi negatif (tidak mendukung) pada data sample untuk kriteria tertentu.

$$
\begin{aligned}
& (,)= \\
& ()-\Sigma \quad \text { ( ) } \frac{1 \mid}{1 \mid} \quad(\quad)
\end{aligned}
$$

Dimana :

$\mathrm{S} \quad=$ ruang (data) sample yang digunakan untuk training.

A $=$ atribut.

$\mathrm{V}=$ Suatu nilai yang mungkin untuk atribut A.

Nilai $(A)=$ Himpunan yang mungkin untuk atribut A.

$|\mathrm{Sv}|=$ Jumlah sample untuk nilai $\mathrm{V}$.

$|\mathrm{S}| \quad=$ jumlah seluruh sample data.

Entropy $(\mathrm{Sv})=$ entropy untuk sample-sample yang memiliki nilai $\mathrm{V}$.

3. Bentuk simpul yang berisi atribut tersebut.

4. Ulangi proses perhitungan information gain yang akan terus dilaksanakan sampai semua data telah termasuk dalam kelas yang sama. Atribut yang telah dipilih tidak diikutkan lagi dalam perhitungan nilai information gain.

Adapun sample data yang digunakan oleh ID3 memiliki beberapa syarat (Setiawan, 2010), yaitu:

1. Deskripsi atribut-nilai. Atribut yang sama harus mendeskripsikan tiap contoh dan memiliki jumlah nilai yang sudah ditentukan.

2. Kelas yang sudah didefinisikan sebelumnya. Suatu atribut contoh harus sudah didefinisikan, karena mereka tidak dipelajari oleh ID3.

3. Kelas-kelas yang diskrit. Kelas harus digambarkan dengan jelas. Kelas yang kontinu 
dipecah-pecah menjadi kategori-kategori yang relatif.

4. Jumlah contoh (example) yang cukup. Karena pembangkitan induktif digunakan, maka dibutuhkan test case yang cukup untuk membedakan pola yang valid dari peluang suatu kejadian.

Pemillihan atribut pada ID3 dilakukan dengan properti statistik, yang disebut dengan Information Gain (IG). Information Gain atau bisa juga disebut Gain digunakan untuk mengukur seberapa baik suatu atribut memisahkan training example ke dalam kelas target. Atribut dengan informasi tertinggi akan dipilih. Dengan tujuan untuk mendefinisikan gain, pertama-tama digunakanlah ide dari teori informasi yang disebut entropi. Entropi mengukur jumlah dari informasi yang ada pada atribut. Tujuan dari pengukuran nilai information gain adalah untuk memilih atribut yang akan dijadikan cabang pada pembentukan pohon keputusan. Pilih atribut yang memiliki nilai information gain terbesar. Algoritma ID3 berhenti jika atribut atau variabel yang dinilai sempurna mengklasifikasikan training sets. Atau secara rekursif mengoperasikan nilai $n$, dimana $n$ adalah banyaknya nilai kemungkinan dari suatu untuk mendapatkan atribut terbaik.

Alasan terbesar menggunakan algoritma ID3 adalah kesederhanaan yang ditawarkan metode ini dalam mengklasifikasikan data. Walau dengan proses yang sederhana, namun dapat menghasilkan hasil klasifikasi yang akurat.

\subsection{Kinerja PNS}

Kinerja PNS ditentukan berdasarkan sistem prestasi dan sistem karir yang dititikberatkan pada sistem prestasi kerja. Sistem penilaian kinerja PNS disebut dengan istilah pembinaan dalam manajemen PNS. Manajemen PNS diarahkan untuk menjamin penyelenggaraan tugas pemerintahan dan pembangunan secara berdayaguna dan berhasil guna.Untuk mewujudkan penyelengaraan tugas pemerintahan dan pembangunan inilah, diperlukan Pegawai Negeri Sipil yang profesional, bertanggung jawab, jujur, dan adil.

Prosedur penilaian kinerja PNS dilakukan oleh masing-masing pimpinan unit kerja. Namun, yang bertanggungjawab mengelolah proses penilaian kinerja adalah Badan Kepegawaian Negara (BKN) yang memiliki perwakilan di masing-masing daerah yaitu Badan Kepegawaian Daerah (BKD). BKD inilah yang akan mengatur semua proses pembinaan dari saat formasi, pengangkatan, penempatan, mutasi, disiplin hingga pemberhentian pegawai.
Sesuai dengan ketentuan Peraturan Pemerintah Nomor 10 Tahun 1979 tentang Penilaian Pelaksanaan Pekerjaan Pegawai Negeri Sipil, diuraikan bahwa yang menjadi unsur-unsur penilaian kinerja PNS adalah

- Kesetiaan, nilai kepatuhan terhadap Pancasila dan Negara Kesatuan Republik Indonesia serta Pemerintah Republik Indonesia.

- Prestasi Kerja, kemampuan untuk menguasai segala bentuk tugas dan pekerjaan sebagai PNS.

- Tanggung Jawab, kemampuan menyelesaikan tugas dengan sebaik-baiknya dan tepat waktu.

- Ketaatan, kepatuhan terhadap Undang-Undang dan Peraturan Pemerintah serta memberikan pelayanan yang maksimal kepada masyarakat.

- Kejujuran, melaksanakan tugas dengan ikhlas dan tidak menyalagunakan wewenang dan jabatan.

- Kerjasama, memiliki kemampuan bekerja dalam tim, menjaga hubungan dengan sesama pegawai.

- Prakarsa, memiliki kemampuan untuk berinisiatif dan kreatif dalam melaksanakan tugas.

- Kepemimpinan, kemampuan untuk memimpin anggota dalam suatu unit kerja. Unsur ini berlaku bagi mereka yang memiliki jabatan.

Semua unsur-unsur ini dituangkan dalam Daftar Penilaian Pelaksanaan Pekerjaan yang disingkat dengan DP3

\section{Metodologi}

Dalam merancang sistem informasi pengukuran kinerja PNS terdapat tahapan-tahapan yang harus dilaksanakan untuk memastikan upaya perancangan sistem mencapai hasil yang maksimal. Tahapan dari prosedur penelitian dimulai dari mengidentifikasi dan merumuskan masalah yang menjadi tujuan utama dari pembangunan sistem informasi pengukuran kinerja ini.

Penentuan atribut atau variabel yang menjadi objek penelitian dengan merujuk pada UndangUndang Republik Indonesia Nomor 43 Tahun 1999 Tentang Perubahan atas Undang-Undang Nomor 8 Tahun 1974 Tentang Pokok-Pokok Kepegawaian. Sedangkan penghitungan nilai Entropy dan Informasi Gain menggunakan Algoritma ID3 yang ditunjukan dengan membangun pohon keputusan berdasarkan nilai Gain terbesar yang telah diperoleh. Tahapan terakhir adalah menghitung tingkat akurasi dari data yang diolah. Adapun prosedur dari penelitian ini ditunjukkan oleh Gambar 2 berikut ini : 


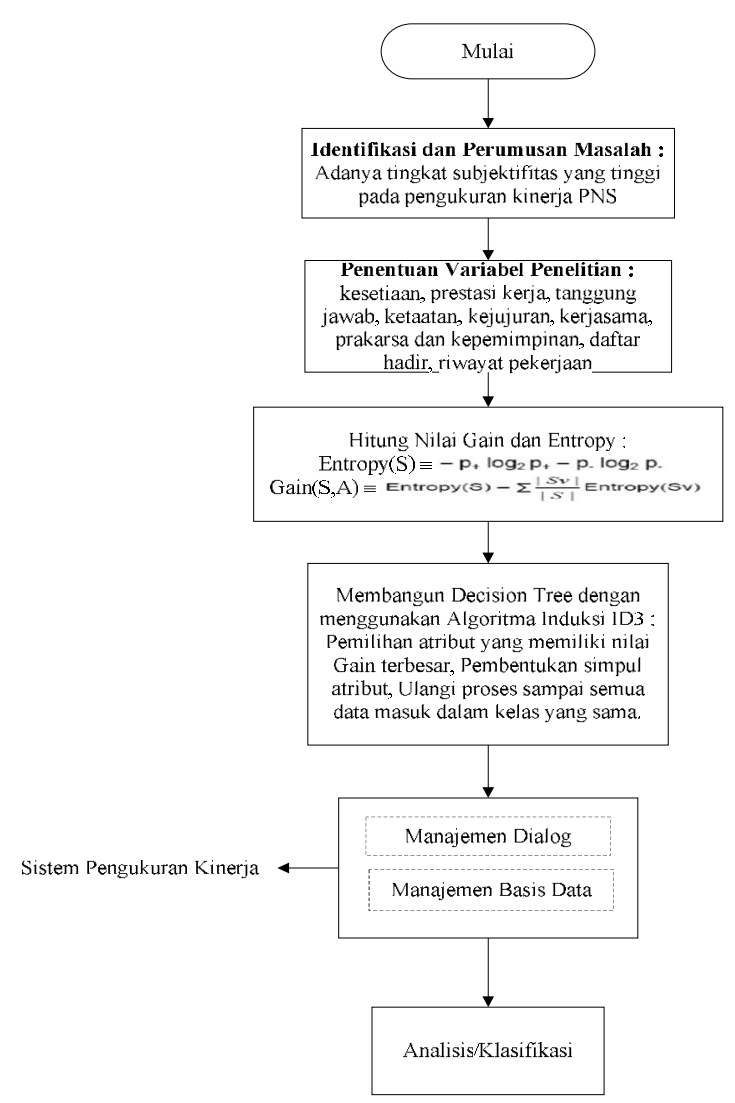

Gambar 2. Diagram langkah-langkah penelitian

\subsection{Membangun Pohon Keputusan dengan Algoritma ID3}

Sebuah objek yang diklasifikasikan dalam pohon keputusan harus diuji nilai entropynya. Entropy adalah ukuran dari teori informasi yang dapat mengetahui karakteristik dari impuryt atau ketidakmurnian dan homogenity atau kesamaan dari kumpulan data. Dari nilai entropy tersebut dihitung nilai information gain masing-masing atribut. Atribut dengan information gain terbesar menjadi root dari pohon keputusan, hirarki selanjutnya mengikuti rangking nilai information gain dari tiap atribut.

\subsection{Deskripsi Variabel}

Setiap variabel memiliki nilai atau kategori sebagai berikut :

- Variabel Kehadiran dikelompokkan dalam 3 kategori yaitu: Ringan, Sedang, dan Berat.

- Variabel Kesetiaan dikelompokkan dalam 3 kategori yaitu: Amat Baik, Baik, dan Cukup.

- Variabel Prestasi Kerja dikelompokkan dalam 3 kategori yaitu: Amat Baik, Baik, dan Cukup.

- Variabel Tanggung Jawab dikelompokkan dalam 3 kategori yaitu: Amat Baik, Baik, dan Cukup.

- Variabel Ketaatan dikelompokkan dalam 3 kategori yaitu: Amat Baik, Baik, dan Cukup.
- Variabel Kejujuran dikelompokkan dalam 3 kategori yaitu: Amat Baik, Baik, dan Cukup.

- Variabel Kerjasama dikelompokkan dalam 3 kategori yaitu: Amat Baik, Baik, dan Cukup.

- Variabel Prakarsa dikelompokkan dalam 3 kategori yaitu: Amat Baik, Baik, dan Cukup.

- Variabel Kepemimpinan dikelompokkan dalam 3 kategori yaitu: AmatBaik, Baik, dan Cukup.

Terdapat 127 sampel pegawai yang diinisialisasikan dalam P1 sampai P127 yang diambil data penilaiannya. Dengan 3 kategori yang dikelompokan dari masing-masing variabel yaitu: amat baik (91-100), baik (76-90), dan cukup (61-75). Dan 3 kategori lagi yaitu: ringan (5-15), sedang (16$30)$, dan berat $(\geq 31)$ untuk kehadiran. Maka untuk data yang lengkap seharusnya terdapat 19683 total kombinasi sampel data, akan tetapi dalam tabel diatas hanya terdapat 127 kombinasi artinya masih ada 19556 kombinasi yang belum diketahui. Dengan penggunaan sistem klasifikasi pohon keputusan menggunakan algoritma ID3, aturan atau data yang belum diketahui bisa kita temukan untuk menentukan kualitas kinerja pegawai.

\subsection{Analisis Information Gain}

Jumlah kelas ada 2, yaitu: Bagus dan Buruk (c = 2). Jumlah sampel kelas (Bagus) adalah 56, dan Jumlah sampel kelas (Buruk) adalah 71, jadi P1 adalah 56 dan P2 adalah 71.

Entropy atau kumpulan sampel data $\mathrm{S}$ adalah:

Entropy $(\mathrm{S})=-(56 / 127) \log 2(56 / 127)-(71 / 127)$ $\log 2(71 / 127)=0,9899$

Atribut Kinerja = "Bagus" merupakan sampel (+), dan atribut Kinerja = "Buruk" merupakan sampel (-), dari sampel data pada tabel, didapat:

Values (nil.Kehadiran) = Ringan, Sedang, Berat.

$\mathrm{S}=[56+, 71-],|\mathrm{S}|=127$

$\mathrm{S}_{\text {Ringan }}=[28+, 17-], \mid$ Ringan $\mid=45$

$\mathrm{S}_{\text {Sedang }}=[28+, 17-], \mid$ Sedang $\mid=45$

$\mathrm{S}_{\text {Berat }}=[0+, 37-], \mid$ Berat $\mid=37$

Hitung entropy $\mathrm{S}_{\text {Ringan, }} \mathrm{S}_{\text {Sedang, }} \mathrm{S}_{\text {Berat }}$ sebagai berikut:

Entropy $(\mathrm{S})=0,9899$

Entropy $\left(\mathrm{S}_{\text {Ringan }}\right)=(-28 / 45) \log _{2}(28 / 45)-(17 / 45)$

$\log _{2}(17 / 45)=0,9565$

Entropy $\left(\mathrm{S}_{\text {Sedang }}\right)=(-28 / 45) \log _{2}(28 / 45)-(17 / 45)$

$\log _{2}(17 / 45)=0,9565$

Entropy $\left(\mathrm{S}_{\text {Berat }}\right) \quad=(-0 / 37) \log _{2}(0 / 37)-(37 / 37) \log _{2}$ $(37 / 37)=0$

Information Gain (S, Nil.Kehadiran)

$=$ Entropy

(S)

$$
\begin{aligned}
& \sum_{(}, \underset{1}{\frac{1}{||}} \quad(\quad) \\
& =0,9899-((45 / 127) * 0,9565)-((45 / 127) * 0,9565)- \\
& ((37 / 127) * 0) \\
& =0,9899-0,3389-0,3389-0 \\
& =\mathbf{0 , 3 1 2 1}
\end{aligned}
$$

Values $($ nil.Kesetiaan $)=$ Amat Baik, Baik, Cukup $\mathrm{S}=[56+, 71-],|\mathrm{S}|=127$ 


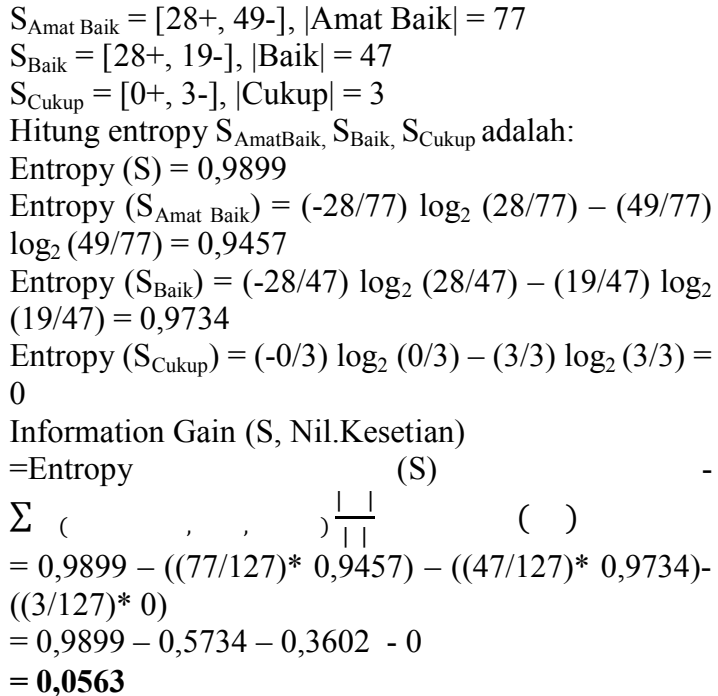

Values (nil.Prestasi Kerja) $=$ Amat Baik, Baik, Cukup

$\mathrm{S}=[56+, 71-],|\mathrm{S}|=127$

$\mathrm{S}_{\text {Amat Baik }}=[28+, 44-], \mid$ Amat Baik $\mid=72$

$\mathrm{S}_{\text {Baik }}=[28+, 21-], \mid$ Baik $\mid=49$

$\mathrm{S}_{\text {Cukup }}=[0+, 6-], \mid$ Cukup $\mid=6$

Hitung entropy $\mathrm{S}_{\text {AmatBaik}}, \mathrm{S}_{\text {Baik}}, \mathrm{S}_{\text {Cukup }}$ adalah:

Entropy $(\mathrm{S})=0,9899$

Entropy $\left(\mathrm{S}_{\text {Amat Baik }}\right)=(-28 / 72) \log _{2}(28 / 72)-(44 / 72)$ $\log _{2}(44 / 72)=0,9641$

Entropy $\left(\mathrm{S}_{\text {Baik }}\right)=(-28 / 49) \log _{2}(28 / 49)-(21 / 49) \log _{2}$ $(21 / 49)=0,9852$

Entropy $\left(\mathrm{S}_{\text {Cukup }}\right)=(-0 / 6) \log _{2}(0 / 6)-(6 / 6) \log _{2}(6 / 6)=$ 0

Information Gain (S, Nil.Prestasi Kerja)

$=$ Entropy

$\left.\sum_{(} \quad, \quad\right) \frac{1}{1 \mid} \quad(\quad)$

$=0,9899-((72 / 127) * 0,9641)-((49 / 127) * 0,9852)$ -

$((6 / 127) * 0)$

$=0,9899-0,5466-0,3801-0$

$=0,0632$

Values (nil.Tanggung Jawab) = Amat Baik, Baik, Cukup

$\mathrm{S}=[56+, 71-],|\mathrm{S}|=127$

$\mathrm{S}_{\text {Amat Baik }}=[28+, 39-], \mid$ Amat Baik $\mid=67$

$\mathrm{S}_{\text {Baik }}=[28+, 23-], \mid$ Baik $\mid=51$

$\mathrm{S}_{\text {Cukup }}=[0+, 9-], \mid$ Cukup $\mid=9$

Hitung entropy $S_{\text {AmatBaik, }} S_{\text {Baik, }} S_{\text {Cukup }}$ adalah:

Entropy $(\mathrm{S})=0,9899$

Entropy $\left(\mathrm{S}_{\text {Amat Baik }}\right)=(-28 / 67) \log _{2}(28 / 67)-(39 / 67)$ $\log _{2}(39 / 67)=0,9805$

Entropy $\left(\mathrm{S}_{\text {Baik }}\right)=(-28 / 51) \log _{2}(28 / 51)-(23 / 51) \log _{2}$ $(23 / 51)=0,9931$

Entropy $\left(\mathrm{S}_{\text {Cukup }}\right)=(-0 / 9) \log _{2}(0 / 9)-(9 / 9) \log _{2}(9 / 9)=$ 0

Information Gain (S, Nil. Tanggung Jawab)
$=$ Entropy

$\sum$

(S)

$=0,9899-((67 / 127) * 0,9805)-((51 / 127) * 0,9931)$ -

$((9 / 127) * 0)$

$=0,9899-0,5173-0,3988-0$

$=\mathbf{0 , 0 7 3 9}$

Values $($ nil.Ketaatan $)=$ Amat Baik, Baik, Cukup

$\mathrm{S}=[56+, 71-],|\mathrm{S}|=127$

$\mathrm{S}_{\text {Amat Baik }}=[28+, 34-], \mid$ Amat Baik $\mid=62$

$\mathrm{S}_{\text {Baik }}=[28+, 25-], \mid$ Baik $\mid=53$

$\mathrm{S}_{\text {Cukup }}=[0+, 12-], \mid$ Cukup $\mid=12$

Hitung entropy $\mathrm{S}_{\text {AmatBaik, }} \mathrm{S}_{\text {Baik, }} \mathrm{S}_{\text {Cukup }}$ adalah:

Entropy $(S)=0,9899$

Entropy $\left(\mathrm{S}_{\text {Amat Baik }}\right)=(-28 / 62) \log _{2}(28 / 62)-(34 / 62)$ $\log _{2}(34 / 62)=0,9932$

Entropy $\left(\mathrm{S}_{\text {Baik }}\right)=(-28 / 53) \log _{2}(28 / 53)-(25 / 53) \log _{2}$ $(25 / 53)=0,9977$

Entropy $\left(\mathrm{S}_{\text {Cukup }}\right)=(-0 / 12) \log _{2}(0 / 12)-(12 / 12) \log _{2}$ $(12 / 12)=0$

Information Gain (S, Nil. Ketaatan)

$=$ Entropy

$\sum(\quad, \quad) \frac{1}{11}$

$=0,9899-((62 / 127) * 0,9932)-((53 / 127) * 0,9977)$ -

$((12 / 127) * 0)$

$=0,9899-0,4849-0,4161-0$

$=0,0887$

Values (nil.Kejujuran) = Amat Baik, Baik, Cukup

$\mathrm{S}=[56+, 71-],|\mathrm{S}|=127$

$\mathrm{S}_{\text {Amat Baik }}=[28+, 29-], \mid$ Amat Baik $\mid=57$

$\mathrm{S}_{\text {Baik }}=[28+, 27-], \mid$ Baik $\mid=55$

$\mathrm{S}_{\text {Cukup }}=[0+, 15-], \mid$ Cukup $\mid=15$

Hitung entropy $\mathrm{S}_{\text {AmatBaik, }} \mathrm{S}_{\text {Baik}}, \mathrm{S}_{\text {Cukup }}$ adalah:

Entropy $(\mathrm{S})=0,9899$

Entropy $\left(\mathrm{S}_{\text {Amat Baik }}\right)=(-28 / 57) \log _{2}(28 / 57)-(29 / 57)$ $\log _{2}(29 / 57)=0,9998$

Entropy $\left(\mathrm{S}_{\text {Baik }}\right)=(-28 / 55) \log _{2}(28 / 55)-(27 / 55) \log _{2}$ $(27 / 55)=0,9998$

Entropy $\left(\mathrm{S}_{\text {Cukup }}\right)=(-0 / 15) \log _{2}(0 / 15)-(15 / 15) \log _{2}$ $(15 / 15)=0$

Information Gain (S, Nil. Kejujuran)

$=$ Entropy

(S)

$\left.\Sigma_{(}, \quad, \quad\right) \frac{1}{11} \quad(\quad)$

$=0,9899-((57 / 127) * 0,9998)-((55 / 127) * 0,9998)$ $\left((15 / 127)^{*} 0\right)$

$=0,9899-0,4487-0,4330-0$

$=\mathbf{0 , 1 0 8 2}$

Values $($ nil.Kerjasama $)=$ Amat Baik, Baik, Cukup $\mathrm{S}=[56+, 71-],|\mathrm{S}|=127$

$\mathrm{S}_{\text {Amat Baik }}=[28+, 24-], \mid$ Amat Baik $\mid=52$

$\mathrm{S}_{\text {Baik }}=[28+, 29-], \mid$ Baik $\mid=57$

$\mathrm{S}_{\text {Cukup }}=[0+, 18-], \mid$ Cukup $\mid=18$

Hitung entropy $\mathrm{S}_{\text {AmatBaik, }} \mathrm{S}_{\text {Baik, }}, \mathrm{S}_{\text {Cukup }}$ adalah:

Entropy $(\mathrm{S})=0,9899$ 
Entropy $\left(\mathrm{S}_{\text {Amat Baik }}\right)=(-28 / 52) \log _{2}(28 / 52)-(24 / 52)$ $\log _{2}(24 / 52)=0,9957$

Entropy $\left(\mathrm{S}_{\text {Baik }}\right)=(-28 / 57) \log _{2}(28 / 57)-(29 / 57) \log _{2}$ $(29 / 57)=0,9998$

Entropy $\left(\mathrm{S}_{\text {Cukup }}\right)=(-0 / 18) \log _{2}(0 / 18)-(18 / 18) \log _{2}$ $(18 / 18)=0$

Information Gain (S, Nil. Kerjasama)

$$
\begin{aligned}
& =\text { Entropy } \\
& \left.\sum_{(}, \quad\right) \frac{\mid}{||} \quad(\mathrm{S}) \\
& =0,9899-((52 / 127) * 0,9957)-\left((57 / 127)^{*} 0,9998\right)- \\
& ((18 / 127) * 0) \\
& =0,9899-0,4077-0,4487-0 \\
& =\mathbf{0 , 1 3 3 5}
\end{aligned}
$$

Values $($ nil.Prakarsa $)=$ Amat Baik, Baik, Cukup

$\mathrm{S}=[56+, 71-],|\mathrm{S}|=127$

$\mathrm{S}_{\text {Amat Baik }}=[28+, 19-], \mid$ Baik $\mid=47$

$\mathrm{S}_{\text {Baik }}=[28+, 31-], \mid$ Baik $\mid=59$

$\mathrm{S}_{\text {Cukup }}=[0+, 21-], \mid$ Cukup $\mid=21$

Hitung entropy $\mathrm{S}_{\text {AmatBaik, }} \mathrm{S}_{\text {Baik, }} \mathrm{S}_{\text {Cukup }}$ adalah:

Entropy $(\mathrm{S})=0,9899$

Entropy $\left(\mathrm{S}_{\text {Amat Baik }}\right)=(-28 / 47) \log _{2}(28 / 47)-(19 / 47)$ $\log _{2}(19 / 47)=0,9734$

Entropy $\left(\mathrm{S}_{\text {Baik }}\right)=(-28 / 59) \log _{2}(28 / 59)-(31 / 59) \log _{2}$ $(31 / 59)=0,9981$

Entropy $\left(\mathrm{S}_{\text {Cukup }}\right)=(-0 / 21) \log _{2}(0 / 21)-(21 / 21) \log _{2}$ $(21 / 21)=0$

Information Gain (S, Nil. Prakarsa)

$=$ Entropy

$\left.\Sigma_{(} \quad, \quad\right) \frac{1}{1 \mid} \quad(\quad)$

$=0,9899-((47 / 127) * 0,9734)-((59 / 127) * 0,9981)-$

$((21 / 127) * 0)$

$=0,9899-0,3602-0,4637-0$

$=\mathbf{0 , 1 6 6 0}$

Values (nil.Kepemimpinan) $=$ Amat Baik, Baik, Cukup

$\mathrm{S}=[56+, 71-],|\mathrm{S}|=127$

$\mathrm{S}_{\text {Amat Baik }}=[28+, 14-], \mid$ Amat Baik $\mid=42$

$\mathrm{S}_{\text {Baik }}=[28+, 14-], \mid$ Baik $\mid=42$

$\mathrm{S}_{\text {Cukup }}=[0+, 43-], \mid$ Cukup $\mid=43$

Hitung entropy $\mathrm{S}_{\text {AmatBaik}}, \mathrm{S}_{\text {Baik, }} \mathrm{S}_{\text {Cukup }}$ adalah:

Entropy $(\mathrm{S})=0,9899$

Entropy $\left(\mathrm{S}_{\text {Amat Baik }}\right)=(-28 / 42) \log _{2}(28 / 42)-(14 / 42)$

$\log _{2}(14 / 42)=0,9183$

Entropy $\left(\mathrm{S}_{\text {Baik }}\right)=(-28 / 42) \log _{2}(28 / 42)-(14 / 42) \log _{2}$ $(14 / 42)=0,9183$

Entropy $\left(\mathrm{S}_{\text {Cukup }}\right)=(-0 / 43) \log _{2}(0 / 43)-(43 / 43) \log _{2}$ $(43 / 43)=0$

Information Gain (S, Nil. Kepemimpinan)

$=$ Entropy

$\sum(\quad, \quad) \frac{1}{1 \mid} \quad(\quad)$

$=0,9899-((42 / 127) * 0,9183)-((42 / 127) * 0,9183)$ -

$\left((43 / 127)^{*} 0\right)$

$=0,9899-0,3037-0,3037-0$

$=\mathbf{0 , 3 8 5 2}$
Dari nilai Information Gain sebanyak sembilan atribut yaitu; Kehadiran, Kesetiaan, Prestasi Kerja, Tanggung Jawab, Ketaatan, Kejujuran, Kerjasama, Prakarsa, dan Kepemimpinan diakumulasi sebagai berikut:

IG (S, Nil. Kehadiran) $\quad=\mathbf{0}, 3121$

IG (S, Nil. Kesetiaan) $\quad=\mathbf{0 , 0 5 6 3}$

IG (S, Nil. Prestasi Kerja) $\quad=\mathbf{0 , 0 6 3 2}$

IG (S, Nil. Tanggung Jawab) $\quad=\mathbf{0 , 0 7 3 9}$

IG (S, Nil. Ketaatan) $\quad=\mathbf{0 , 0 8 8 7}$

IG (S, Nil. Kejujuran) $\quad=\mathbf{0 , 1 0 8 2}$

IG (S, Nil. Kerjasama) $\quad=\mathbf{0 , 1 3 3 5}$

IG (S, Nil. Prakarsa) $\quad=\mathbf{0 , 1 6 6 0}$

IG (S, Nil. Kepemimpinan) $\quad=\mathbf{0 , 3 8 5 2}$

Dari kesembilan nilai Information Gain tersebut, Gain (S, Nil.Kepemimpinan) adalah yang terbesar, sehingga atribut Kehadiran adalah best classifier dan harus diletakkan sebagai root.

\section{Hasil Dan Pembahasan}

\subsection{Iterasi Pohon Keputusan}

Pohon keputusan dibangun dengan memanggil fungsi ID3 dari kumpulan atribut berupa semua sampel data $=[56+, 71-]$. Atribut target $=$ 'Kinerja' dan kumpulan atribut [Kehadiran, Kesetiaan, Prestasi Kerja, Tanggung Jawab, Ketaatan, Kejujuran, Kerjasama, Prakarsa, dan Kepemimpinan]. Variabel dengan nilai Information Gain yang terbesar akan menentukan best classifier dan diletakan sebagai root.

Dari penjelasan pada bab sebelumnya, didapat nilai Information Gain (Kepemimpinan) sebagai best classifier sehingga atribut kepemimpinan diletakan sebagai root. Langkah selanjutnya adalah menguji setiap nilai pada atribut kepemimpinan untuk membuat sub tree dilevel berikutnya. Atribut kepemimpinan memiliki 3 sampel (Amat Baik, Baik, dan Cukup). Untuk nilai 'amat baik' terdapat 42 sampel, berarti sampel amat baik tidak kosong, sehingga perlu memanggil fungsi ID3 dengan kumpulan sampel ringan $=[28+, 14-]$. Visualisasi pohon keputusan untuk atribut kepemimpinan dengan sampel amat baik digambarkan seperti gambar 3 berikut.

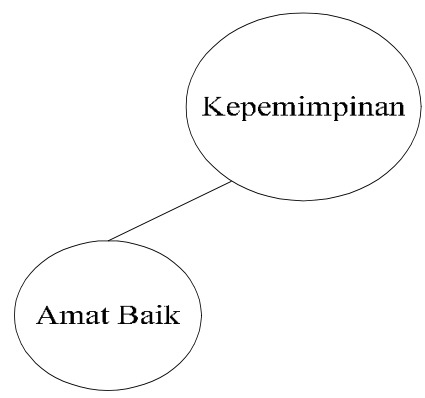

Gambar 3. Pohon keputusan atribut kepemimpinan sampel amat baik 
Kumpulan sampel Amat Baik $=[28+, 14-]$ atribut target 'kinerja', dengan 2 nilai yang dimiliki ini maka pada tahap ini dilakukan perhitungan Information Gain untuk atribut (kehadiran, kesetiaan, prestasi kerja, tanggung jawab, ketaatan, kejujuran, kerjasama, dan prakarsa) tetapi hanya pada sampel amat baik.

Hasil perhitungan Information Gain diakumulasi sebagai berikut:

$\begin{array}{ll}\text { IG }(\text { S, Nil. Kehadiran) } & =\mathbf{0 , 9 1 8 3} \\ \text { IG (S, Nil. Kesetiaan) } & =\mathbf{0 , 0 0 0 1} \\ \text { IG (S, Nil. Prestasi Kerja) } & =\mathbf{0 , 0 0 0 1} \\ \text { IG (S, Nil. Tanggung Jawab) } & =\mathbf{0 , 0 0 0 1} \\ \text { IG (S, Nil. Ketaatan) } & =\mathbf{0 , 0 0 0 1} \\ \text { IG (S, Nil. Kejujuran) } & =\mathbf{0 , 0 0 0 1} \\ \text { IG (S, Nil. Kerjasama) } & =\mathbf{0 , 0 0 0 1} \\ \text { IG (S, Nil. Prakarsa) } & =\mathbf{0 , 0 0 0 1}\end{array}$

Dari kedelapan nilai Information Gaindiatas, Gain(kehadiran) yang terbesar sehingga Kehadiran adalah atribut best classifier yang harus diletakan sebagai simpul dibawah simpul Kepemimpinan pada cabang 'amat baik'. Visualisasi pohon keputusan untuk simpul kehadiran seperti gambar 4 . berikut.

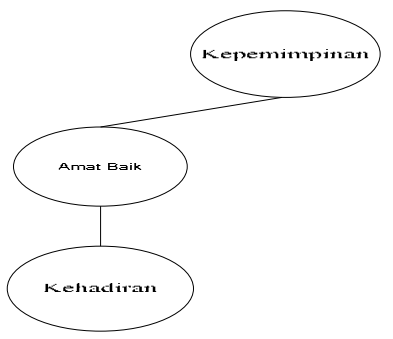

Gambar 4. Pohon keputusan atribut kehadiran

Selanjutnya, setiap nilai pada atribut Kehadiran dan akan dicek apakah perlu dibuat subtree dilevel berikutnya atau tidak. Untuk nilai 'Ringan' pada atribut Kehadiran dari kumpulan sampel Kepemimpinan 'Amat Baik' [28+, 14-], terdapat 14 sampel berarti sampel Amat Baik tidak kosong. Sehingga perlu memanggil fungsi ID3 dengan sampel Amat Baik [14+,0-]. Visualisasi pohon keputusan atribut kehadiran dengan nilai ringan seperti pada Gambar 5.

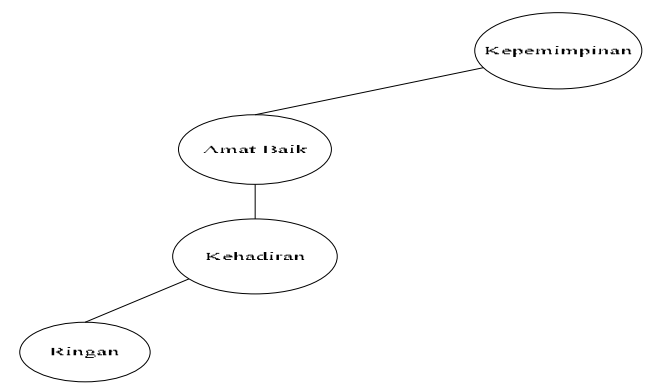

Gambar 5. Pohon keputusan atribut kehadiran nilai ringan
Dari kumpulan sampel ringan pada atribut Kehadiran $[14+, 0-]$ dengan atribut target Kinerja, semua sampel termasuk pada dalam kelas 'Bagus'. Maka fungsi ini akan berhenti dan mengembalikan satu simpul tunggal root dengan label 'Bagus' seperti pada gambar 6 .

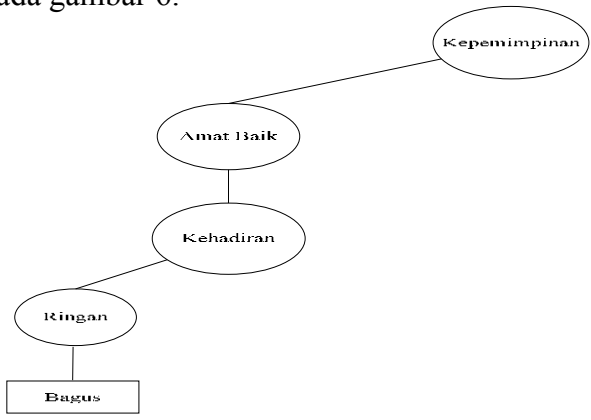

Gambar 6. Pohon keputusan kehadiran ringan label bagus

Selanjutnya, dilakukan pengecekan pada atribut Kehadiran dengan nilai 'Sedang' terdapat 14 sampel dari kumpulan atribut Kepemimpinan 'Amat Baik' [28+, 14-] berarti sampel Sedang tidak kosong. Sehingga perlu memanggil fungsi ID3 dengan sampel Sedang [14+, 0-]. Visualisasi pohon keputusan untuk nilai 'Sedang' pada atribut Kehadiran seperti Gambar 7 berikut.

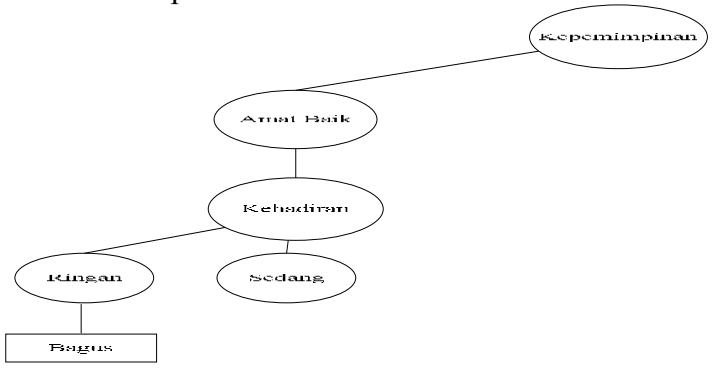

Gambar 7. Pohon keputusan atribut kehadiran nilai sedang

Dari kumpulan sampel Sedang pada atribut Kehadiran $[14+, 0-]$ dengan atribut target Kinerja, semua sampel termasuk pada dalam kelas 'Bagus'. Maka fungsi ini akan berhenti dan mengembalikan satu simpul tunggal root dengan label 'Bagus' seperti pada gambar 8 .

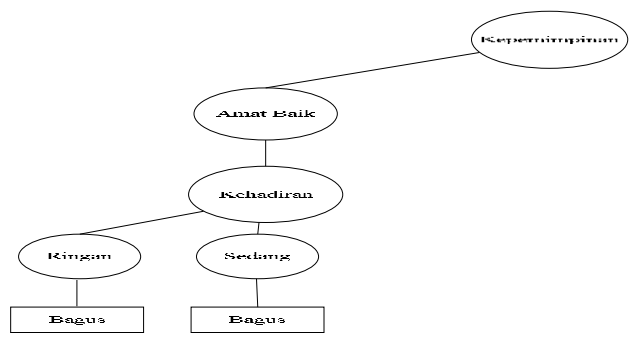

Gambar 8. Pohon keputusan atribut kehadiran sedang label bagus 
Selanjutnya, dilakukan pengecekan pada atribut Kehadiran dengan nilai 'Berat' terdapat 14 sampel dari kumpulan atribut Kepemimpinan 'Amat Baik'[28+, 14-] berarti sampel Berat tidak kosong. Sehingga perlu memanggil fungsi ID3 dengan sampel Cukup [0+, 14-]. Visualisasi pohon keputusan untuk nilai 'Berat' pada atribut Kehadiran seperti Gambar 9. berikut.

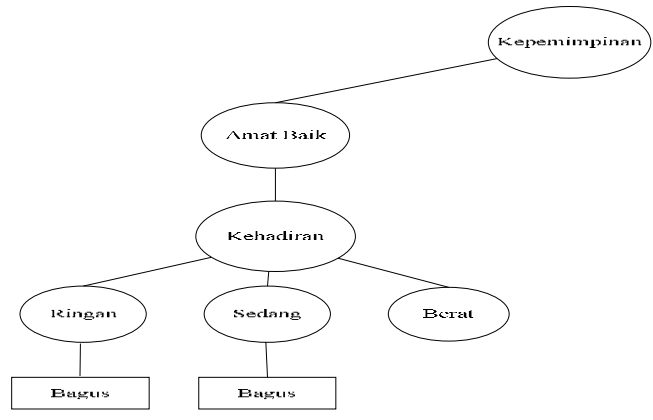

Gambar 9. Pohon keputusan atribut kehadiran nilai berat

Dari kumpulan sampel Berat pada atribut Kehadiran $[0+, 14-]$ dengan atribut target Kinerja, semua sampel termasuk pada dalam kelas 'Buruk'. Maka fungsi ini akan berhenti dan mengembalikan satu simpul tunggal root dengan label 'Buruk' seperti pada gambar 10 .

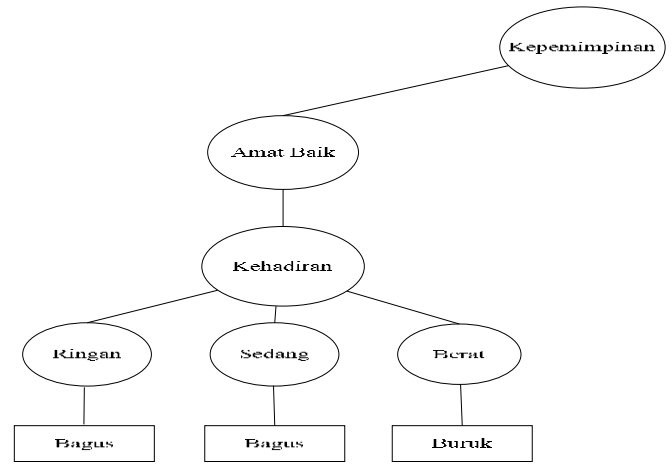

Gambar 10. Pohon keputusan kehadiran berat label buruk

Untuk nilai 'Baik' terdapat 42 sampel, berarti sampel Baik tidak kosong sehingga perlu memanggil fungsi ID3 dengan kumpulan sampel $=[28+, 14-]$ artibut target 'Kinerja'. Dengan 2 nilai yang dimiliki maka pada tahap ini dilakukan perhitungan Information Gain untuk atribut (kehadiran, kesetiaan, prestasi kerja, tanggung jawab, ketaatan, kejujuran, kerjasama, dan prakarsa) tetapi hanya pada sampel sedang. Hasil perhitungan Information Gain untuk sampel sedang diakumulasi sebagai berikut:

$\begin{array}{ll}\text { IG (S, Nil. Kehadiran) } & =\mathbf{0 , 9 1 8 3} \\ \text { IG (S, Nil. Kesetiaan) } & =\mathbf{0 , 0 0 0 1} \\ \text { IG (S, Nil. Prestasi Kerja) } & =\mathbf{0 , 0 0 0 1}\end{array}$

$\begin{array}{ll}\text { IG (S, Nil. Tanggung Jawab) } & =\mathbf{0 , 0 0 0 1} \\ \text { IG (S, Nil. Ketaatan) } & =\mathbf{0 , 0 0 0 1} \\ \text { IG (S, Nil. Kejujuran) } & =\mathbf{0 , 0 0 0 1} \\ \text { IG (S, Nil. Kerjasama) } & =\mathbf{0 , 0 0 0 1} \\ \text { IG (S, Nil. Prakarsa) } & =\mathbf{0 , 0 0 0 1}\end{array}$

Dari hasil perhitungan Information Gainkedelapan atribut diatas didapati atribut kehadiran memiliki nilai yang paling tinggi, sehingga atribut Kehadiran diletak dibawah simpul Kepemimpinan pada cabang 'Baik'. Visualisasi pohon keputusan untuk simpul kehadiran seperti gambar 11. berikut.

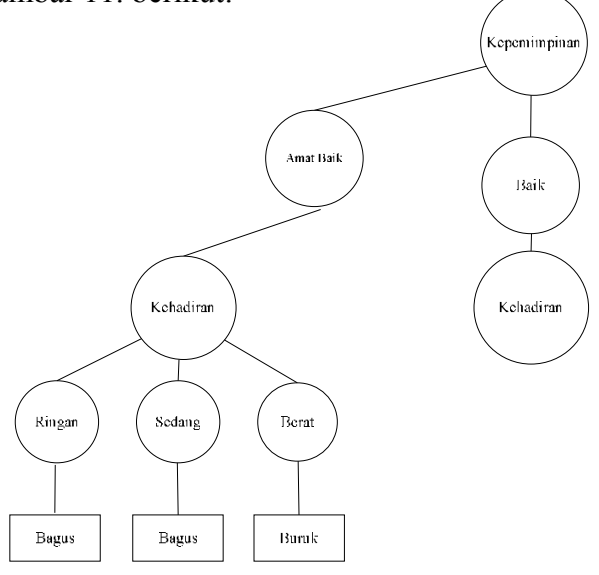

Gambar 11. Pohon keputusan atribut kepemimpinan nilai baik

Selanjutnya, setiap nilai pada atribut Kehadiran akan dicek apakah perlu dibuat subtree dilevel berikutnya atau tidak. Untuk nilai 'Ringan' pada atribut Kehadiran dari kumpulan sampel Kepemimpinan 'Baik' [28+, 14-], terdapat 14 sampel berarti sampel Ringan tidak kosong. Sehingga perlu memanggil fungsi ID3 dengan sampel Ringan [14+,0-]. Visualisasi pohon keputusan atribut kehadiran dengan nilai ringan seperti pada Gambar 12.

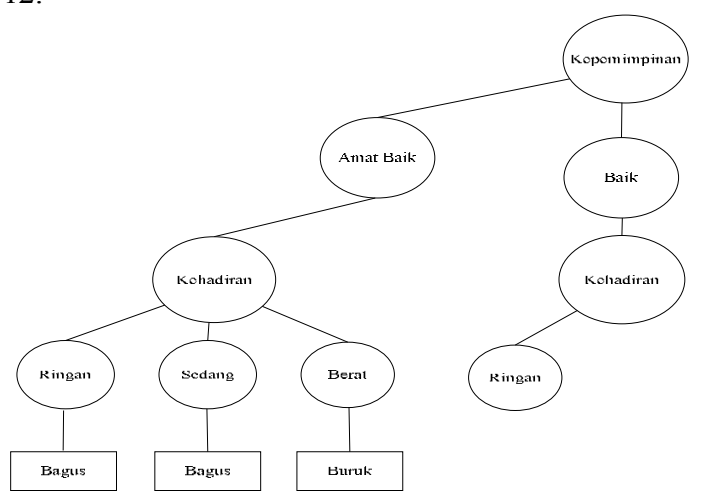

Gambar 12. Pohon keputusan atribut kehadiran nilai ringan 
Dari kumpulan sampel Ringan pada atribut Kehadran [14+,0-] dengan atribut target Kinerja, semua sampel termasuk pada dalam kelas 'Bagus'. Maka fungsi ini akan berhenti dan mengembalikan satu simpul tunggal root dengan label 'Bagus' seperti gambar 13.

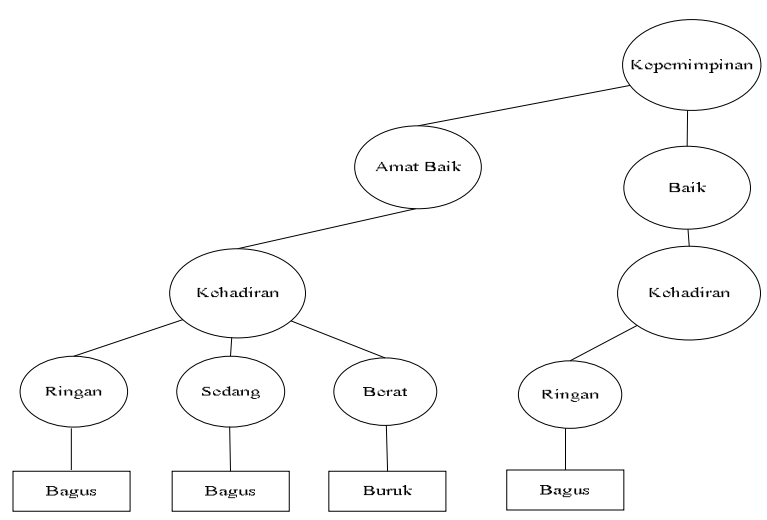

Gambar 13. Pohon keputusan atribut kehadiran ringan label bagus

Untuk nilai 'Sedang' pada atribut Kehadiran dari kumpulan sampel Kepemimpinan 'Baik' [28+, 14-], terdapat 14 sampel berarti sampel Sedang tidak kosong. Sehingga perlu memanggil fungsi ID3 dengan sampel Sedang [14+,0-]. Visualisasi pohon keputusan atribut kehadiran dengan nilai Sedang seperti pada Gambar 14.

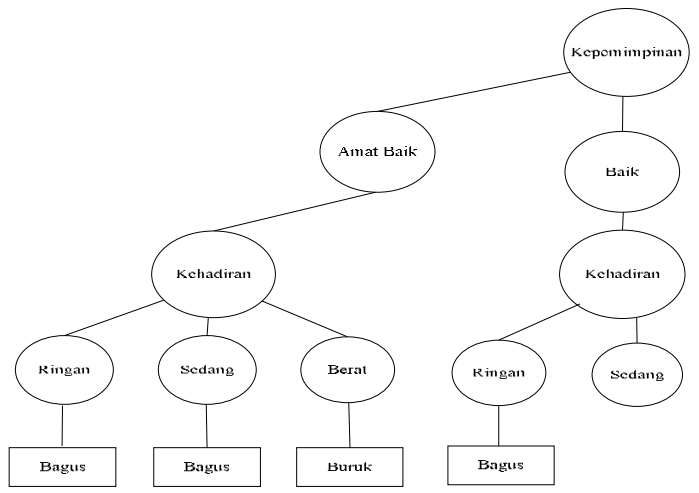

Gambar 14. Pohon keputusan atribut kehadiran nilai sedang

Dari kumpulan sampel Sedang pada atribut Kehadiran $[14+, 0-]$ dengan atribut target Kinerja, semua sampel termasuk pada dalam kelas 'Bagus'. Maka fungsi ini akan berhenti dan mengembalikan satu simpul tunggal root dengan label 'Bagus' seperti gambar 15.

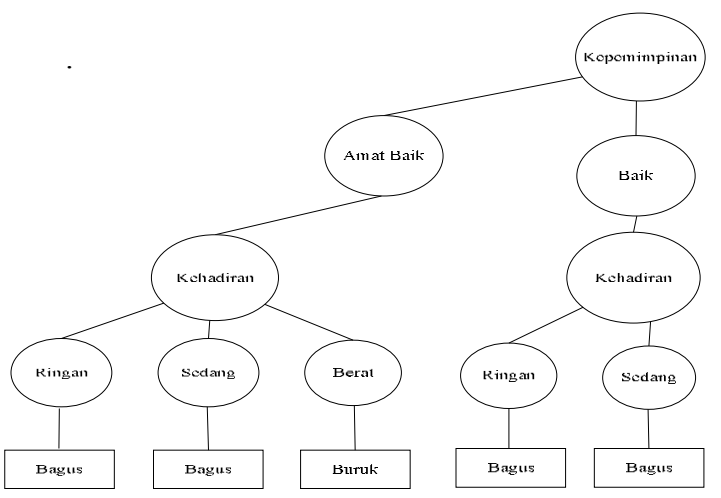

Gambar 15. Pohon keputusan kehadiran sedang label bagus

Untuk nilai 'Berat' pada atribut Kehadiran dari kumpulan sampel Kepemimpinan 'Baik' [28+, 14-], terdapat 14 sampel berarti sampel Berat tidak kosong. Sehingga perlu memanggil fungsi ID3 dengan sampel Berat $[0+, 14-]$. Visualisasi pohon keputusan atribut kehadiran dengan nilai Berat seperti pada Gambar 16.

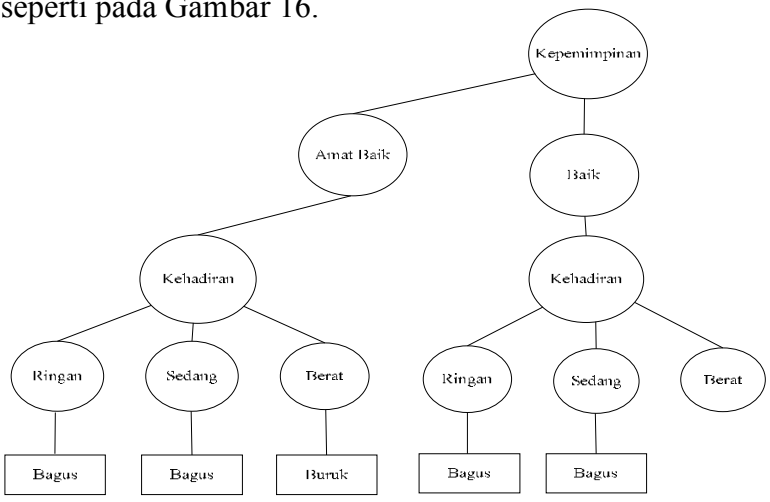

Gambar 16. Pohon keputusan atribut kehadiran nilai berat

Dari kumpulan sampel Berat pada atribut Kehadiran [0+,9-] dengan atribut target Kinerja, semua sampel termasuk pada dalam kelas 'Buruk'. Maka fungsi ini akan berhenti dan mengembalikan satu simpul tunggal root dengan label 'Buruk' seperti gambar 17.

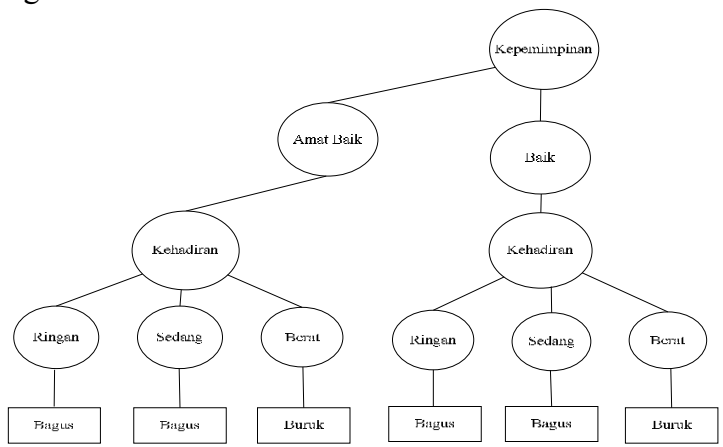

Gambar 17. Pohon keputusan kehadiran berat label buruk 
Untuk nilai 'Cukup' terdapat 43 sampel, berarti sampel Cukup tidak kosong sehingga perlu memanggil fungsi ID3 dengan kumpulan sampel = $[0+, 43-]$ artibut target 'Kinerja' dan kumpulan atribut (kehadiran, kesetiaan, prestasi kerja, tanggung jawab, ketaatan, kejujuran, kerjasama, dan prakarsa). Semua sampel Cukup termasuk dalam kelas 'Buruk' maka fungsi ini akan berhenti dan memberikan satu simpul tunggal root dengan label 'Buruk'. Visualisasi dari pohon keputusan untuk simpul kepemimpinan dengan nilai cukup seperti Gambar 18. berikut.

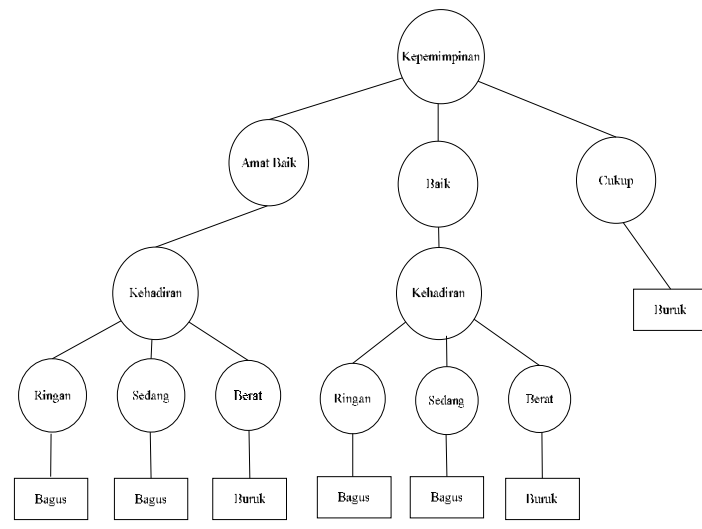

Gambar 18. Pohon keputusan atribut kepemimpinan nilai cukup

Pohon keputusan yang dibentuk seperti pada Gambar 18 diatas menghasilkan aturan sebagai berikut:

1. Jika Kepemimpinan $=$ Amat Baik dan Kehadiran $=$ Ringan maka Kinerja = Bagus,

2. Jika Kepemimpinan $=$ Baik dan Kehadiran $=$ Ringan maka Kinerja = Bagus,

3. Jika Kepemimpinan $=$ Amat Baik dan Kehadiran $=$ Sedang maka Kinerja = Bagus,

4. Jika Kepemimpinan $=$ Baik dan Kehadiran $=$ Sedang maka Kinerja = Bagus,

5. Jika Kepemimpinan $=$ Amat Baik Kehadiran $=$ Berat dan maka Kinerja = Buruk,

6. Jika Kepemimpinan $=$ Baik Kehadiran $=$ Berat dan maka Kinerja = Buruk,

7. Jika Kepemimpinan $=$ Cukup maka Kinerja $=$ Buruk.

\section{Kesimpulan}

Berdasarkan hasil penelitian, dapat diambil beberapa kesimpulan sebagai berikut :

1. Pohon keputusan adalah teknik klasifikasi yang membangun model klasifikasi dari suatu himpunan data masukan. Pohon keputusan menggunakan suatu algoritma pembelajaran untuk mendapatkan model klasifikasi. Sehingga data masukan menjadi hal yang penting pengaruhnya dalam pembentukan pohon keputusan dan aturan yang dihasilkan.
2. Algoritma ID3 dapat menghasilkan pemodelan pohon keputusan dengan proses pemangkasan pohon menjadi lebih sederhana, sehingga cocok untuk data-data yang memiliki tingkat variasi yang komplit.

3. Dengan ditambahkan kehadiran sebagai salah satu unsur dalam penilaian memberikan dampak yang positif dalam memaju tingkat disiplin pegawai dalam hal kehadiran di tempat kerja.

\section{Daftar Pustaka}

Aitkenhead, M.J., 2008. A co-evolving decision tree classification method, Expert Systems with Applications 34, 18-25.

Barak, A., Gelbard, R., 2011. Classification by clustering decision tree-like classifier based on adjusted clusters Expert Systems with Applications 38, 8220-8228.

Balamurugan, S.A, Ramasamy R., 2009. Effective solution for unhandled exception in decision tree induction algorithms, Expert Systems with Applications (36), 12113-12119.

Budiyanto, E., 2013. Sistem Informasi Manajemen Sumber Daya manusia Kerangka Teori dan Pendekatan Teknis, Graha Ilmu, Yogyakarta.

Buku 2, 2012. Pedoman Setifikasi Pendidik untuk Dosen, Penilaian Protofolio, Direktorat Jenderal Pendidikan Tinggi, Kementerian Pendidikan Dan Kebudayaan.

Chen, Y., Hung, L.T., 2009. Using decision trees to summarize associative classification rules, Expert Systems with Applications 36, 2338-2351.

Diana, D.L., Donald, G.G., 2008. Maximal and typical measures of job performance: An analysis of performance variability over time, Human Resource Management Review 18, 133-145.

Defiyanti, S., Pardede, C.D.L., 2009. Perbandingan Kinerja Algoritma ID3 dan C4.5 Dalam Klasifikasi Spam-Mail, Skripsi, Universitas Gunadarma, Jakarta.

Gerdes, M., 2013. Decision trees and genetic algorithms for condition monitoring forecasting of aircraft air conditioning, Expert Systems with Applications 40, 5021-5026

Groen, B.A.C., Wouters J.F, Wilderom C.P.M, 2012. Why do employees take more initiatives to improve their performance after co-developing performance measures? A field study, Elsevier Management Accounting Research 23, 120- 141.

Hermawati, F.A., 2013. Data Mining, Penerbit Andi Offset, Yogyakarta.

Kumar, A., Hanmandlu, M., Gupta, H.M., 2013. Ant colony optimization based fuzzy binary decision tree for bimodal hand knuckle verification system Expert Systems with Applications 40, 439-449.

Lee, C., Song, B., Park, Y., 2012. Design of convergent product concepts based on functionality: An association rule mining and decision tree approach Expert Systems with Applications 39, 9534-9542.

McLean, T., 2009. The measurement and management of human performance in seventeenth century English farming: The case of Henry Best, ElsevierAccounting Forum 33, 62-73.

Noone, B.M., 2008. Customer perceived control and the moderating effect of restaurant type on evaluations of restaurant employee performance, International Journal of Hospitality Management 27, 23-29 
Oetomo, B.S.D., 2006. Perencanaan dan Pembangunan Sistem Informasi, Penerbit Andi, Yogyakarta.

O'Brien, J.A., 2008, Pengantar Sistem Informasi, Prespektif Bisnis dan Manajerial Edisi 12, Penerbit Salemba Empat, Jakarta.

Platts, K.W., Sobotka M, 2010. When the uncountable counts: An alternative to monitoring employee performance, Business Horizons 53, 349-357.

Rahman, R.M., Hasan, F.R.Md., 2011. Using and comparing different decision tree classification techniques for mining ICDDR, B Hospital Surveillance data, Expert Systems with Applications 38, 1142111436.

Safroni, L.M., 2012. Manajemen dan Reformasi Pelayanan Publik dalam Konteks Birokrasi Indonesia, AM Publising, Yogyakarta.

Setiawan, B., 2010, Perancangan sistem pendukung keputusan (SPK) untuk menentukan kelaiklautan kapal : studi kasus di kantor administrasi pelabuhan klas utama tj. perak surabaya, Master Thesis. Institut Teknologi Sepuluh November, Surabaya.
Sindhu, S.S.S., Geetha, S., Kannan, A., 2012. Decision tree based light weight intrusion detection using a wrapper approach, Expert Systems with Applications $39,129-141$.

Sutanta, E., 2003. Sistem Informasi Manajemen, Graha Ilmu, Yogyakarta.

Sutabri, T., 2012. Konsep Sistem Informasi, Penerbit Andi Offset, Yogyakarta.

Ture, M., Fusun, T., Imran, K., 2009. Using Kaplan-Meier analysis together with decision tree methods (C\&RT, CHAID, QUEST, C4.5 and ID3) in determining recurrence-free survival of breast cancer patients, Expert Systems with Applications 36, 2017-2026.

Undang-Undang Republik Indonesia Nomor 43 Tahun 1999. Tentang Perubahan atas Undang-Undang Nomor 8 Tahun 1974 Tentang Pokok-Pokok Kepegawaian.

Wibisono, D., 2011. Manajemen Kinerja Koorporasi dan Organisasi Panduan Penyusunan Indikator, Penerbit Erlangga, Jakarta. 